\title{
15. CALCISPHAERULIDAE AND CALPIONELLIDAE FROM THE UPPER JURASSIC AND LOWER CRETACEOUS OF DEEP SEA DRILLING PROJECT HOLE 416A, MOROCCAN BASIN
}

\author{
Hans M. Bolli, Department of Geology, Swiss Federal Institute of Technology, Zürich, \\ and University of Zürich, Switzerland
}

\section{INTRODUCTION}

Upper Jurassic and Lower Cretaceous Calcisphaerulidae and Calpionellidae were recovered from the Moroccan Basin, Hole 416A, between Cores 8 and 53 (Figure 1). Most of the Calcisphaerulidae specimens are of the spherical Pithonella type, of which the species $P$. thayeri Bolli, $P$. gustafsoni Bolli, $P$. sp. cf. P. sphaerica (Kaufmann), and $P$. sp. E are here distinguished. Further, Calcisphaerulidae tests which are distinctly pear shaped also occur, although much less frequently. Pearshaped tests previously have been reported by Keupp (1977) as Pithonella piriformis, on the basis of SEM views of broken limestone surfaces of the Upper Jurassic Solnhofener Plattenkalk. The characteristic pearshaped tests differ so markedly from the spherical to elongate forms of Pithonella, as do the heart-shaped tests of Bonettocardiella, that the new genus Pirumella is here proposed for pear-shaped Calcisphaerulidae. Pirumella edithvincentae is designated as type species.

Calcisphaerulidae of comparable age (Berriasian to Hauterivian) previously have not been described or figured from SEM studies. Those described by the author from the Indian Ocean (DSDP Leg 27) and the southeastern Atlantic (DSDP Leg 40) are either older (upper Oxfordian to Tithonian) or younger (Aptian to Albian).

Some of the examined samples also contain rare specimens of several calpionellid species: Calpionella alpina Lorenz, Tintinnopsella carpathica (Murgenanu and Filipescu), Calpionellites darderi (Colom), and ?Remaniella murgeanui (Pop). For the purpose of documentation they are also recorded and figured here.

\section{WALL MICROSTRUCTURE AND PRESERVATION}

Identification of the Calpionellidae is largely done on the basis of the shape and size of the lorica, form and position of the collar, and the development of a caudal appendage. These criteria are best recognized in longitudinal axial view as they appear in thin or polished sections of limestones, from which the Calpionellidae are almost exclusively described and figured. The microstructure of the wall, poorly discernible from sections under the light microscope, is not regarded as adequate for identification.

Calcisphaerulidae have also been extensively described from thin sections. Whereas test shape and number of layers are recognizable under the light micro- scope, the individual crystallites making up the layers cannot satisfactorily be distinguished. By the study of isolated Calcisphaerulidae with the scanning electron microscope (SEM), shape and arrangement of the crystallites forming the individual layers provide an important additional criterion in Calcisphaerulidae taxonomy.

SEM investigations of isolated Calcisphaerulidae (Bolli, 1974, 1978a, b) indicate that the following factors influence the initial preservation of tests and our ability to identify them: (a) recrystallization or replacement of the original crystallites forming the test; (b) effects of corrosion on crystallites forming the test wall by $\mathrm{CaCO}_{3}$ dissolution.

The inner space of the test may, under given conditions, either remain hollow or become filled, often with a very dense crystalline calcite core, as in the Hole 416A specimens described here.

It is difficult to determine whether recrystallization or replacement of the original crystallites has taken place in the specimen, and, if replacement, how the replaced material compares with the form and arrangement of the original crystallites. Further, one would need to determine whether such replacement is always identical or whether it varies under differing diagenetic conditions.

Aubry et al. (1975), in discussing ultrastructures of the calpionellid lorica, conclude that they vary with the lithologic nature of the fossilizing environment. Crystallites and their arrangement, however, may remain the same or very similar over wide geographic areas, as illustrated by the similarities within the Upper Cretaceous species Pithonella cooki and $P$. krasheninnikovi. In the Indian Ocean (DSDP Site 260; Gascogne Abyssal Plain) and in the Atlantic (DSDP Site 363; Walvis Ridge), crystallites and the arrangement of their two layers which form the test wall are nearly identical (Bolli, 1974, pl. 7, figs. 1-4; pl. 18, figs. 10-12; pl. 19, figs. 1-12; Bolli, 1978, pl. 3, figs. 1-12).

Partial corrosion or complete dissolution of the outer layer particularly may alter greatly the original test surface. Specimens with a very smooth surface are usually the result of partial or complete dissolution of the crystallites forming the outer surface. Different stages of corrosion and dissolution of the outer wall layer were shown by Bolli (1978, pls. 5 and 6) in a number of specimens identified as Pithonella sp. cf. $P$. sphaerica. One must assume that the surface characters of several Pithonella species described and figured by Bolli (1974) 


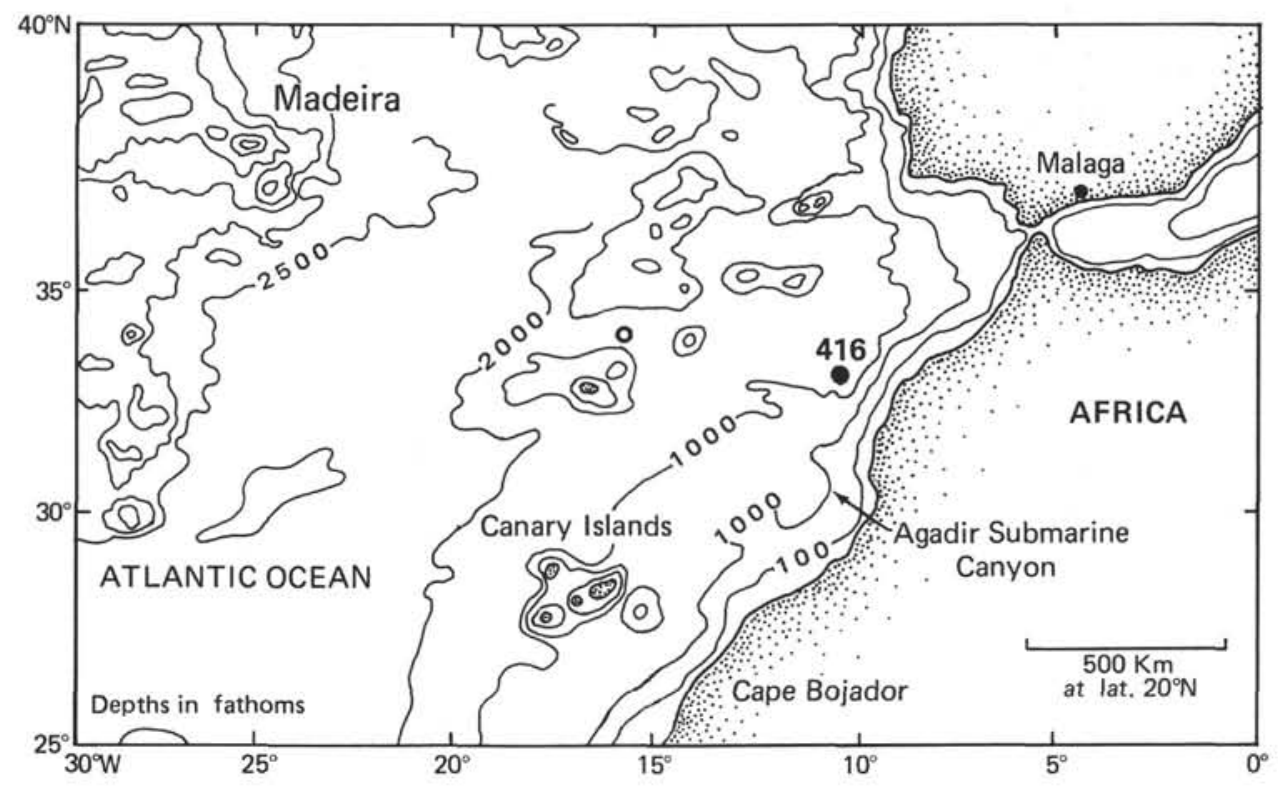

Figure 1. Location of DSDP Site 416.

from the Upper Jurassic and Cretaceous of the Indian Ocean sites of DSDP Leg 27 are also the result of such corrosion, e.g., the smooth-surfaced Pithonella patriciagreelayae. Contrary to the outer surface, where the crystallites forming it are affected by dissolution to a variable degree, the inner surface of the test wall usually consists of well-preserved crystallites with virtually no signs of corrosion.

\section{AGE}

The samples investigated from Hole 416A range from Upper Jurassic (Core 53) to Hauterivian (Core 8) on the basis of the calcareous nannofossils.

Not all stratigraphic occurrences of the isolated specimens of Calpionellidae species from Cores 9, 31, 40, and 45 (figured here) compare with their recorded ages elsewhere. The joint occurrence in Cores 45 and 40 of the species recognized here as Calpionella alpina and Calpionellites darderi differs from their previously recognized distribution. On the basis of present evidence C. alpina ranges only to the top of the Berriasian, whereas $C$. darderi first appears slightly above the basal Valanginian. A joint occurrence of the two species can therefore be explained only by reworking or by the more remote possibility that the older species $C$. alpina may, with some relict forms, have persisted into the Valanginian. Another possible reason for the apparent discrepancies may be that species assignments of some of the isolated specimens are inaccurate. The calpionellid species were originally described from thin sections, and accurate comparison between entire forms and sectioned forms may be more difficult than expected. Further, one has to keep in mind that Lower Cretaceous biostratigraphy, on the basis of calcareous nannofossils, may not exactly coincide with other fossil evidence at the Berriasian-Valanginian and Valanginian-Hauterivian boundary.

Although the presence of Tintinnopsella carpathica in the Valanginian of Core 31 is in good agreement with other fossil evidence, the presence of the same species and of ?Remaniella morgeanu in the Hauterivian of Core 9 is not. Reworking seems the only explanation for the occurrence of the very rare specimens of these two species as high as Hauterivian in the sample in hand.

\section{SAMPLES INVESTIGATED}

In addition to the Hole 416A samples listed in Figure 2 , the following samples were also studied, but did not contain Calcisphaerulidae or Calpionellidae: Samples $11-5,47-49 \mathrm{~cm} ; 18-1,67-69 \mathrm{~cm} ; 25-1,58-60 \mathrm{~cm} ; 28-2$, 2-4 cm; 45-1, 36-38 cm; and 53-1, 21-23 cm.

The species ranges shown on Figure 2 are mainly those determined by the SEM. Study of more specimens by this method from the stratigraphic interval could well extend the ranges.

\section{METHODS OF INVESTIGATION}

Ten $\mathrm{cm}^{3}$ of sediment were disintegrated in diluted $\mathrm{H}_{2} \mathrm{O}_{2}$ and washed through a set of sieves, the finest with 63- and 44-micron openings. Most of the Calcisphaerulidae and Calpionellidae were retained in the 44-mesh screen; some larger specimens were retained in the $63-$ mesh sieve. The dried residue fractions were inspected under the binocular microscope, and specimens were selected for SEM photography. Because details of the wall structure and the number of layers are not recognizable under the light microscope, the species determinations and the record of their stratigraphic occur- 


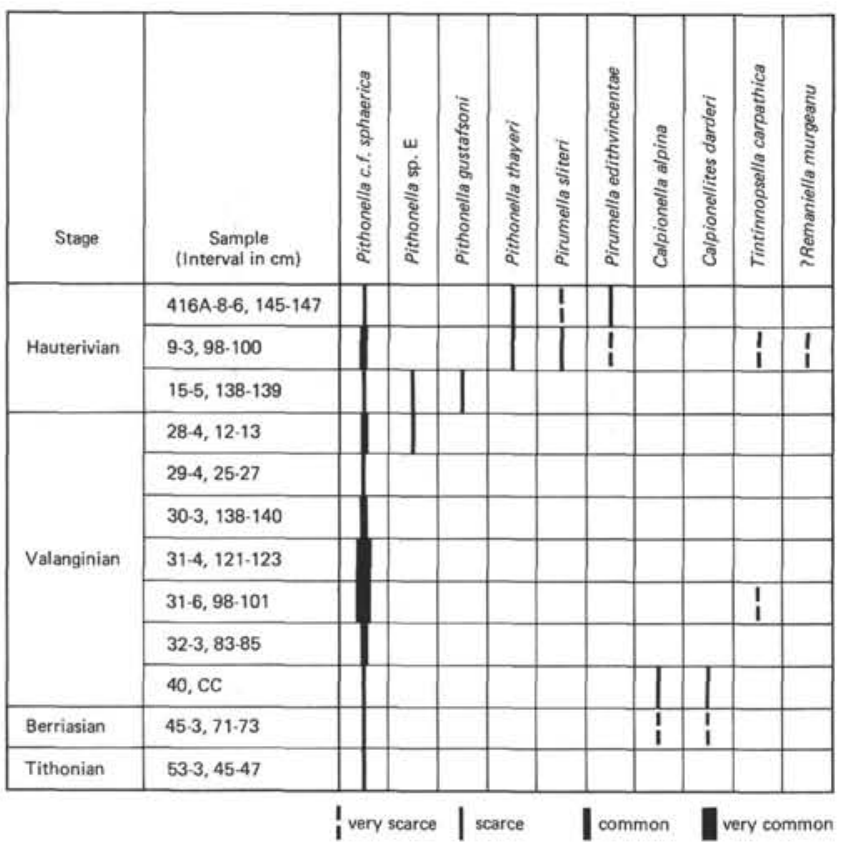

Figure 2. Occurrence and frequency of Calcisphaerulidae and Calpionellidae in the investigated Upper Jurassic and Lower Cretaceous samples of Hole 416 A. Stages are based on calcareous-nannoplankton evidence.

rences largely depend on the amount of SEM work. For the present study, some 400 SEM photographs were taken, of which 84 are reproduced on Plates 1-7.

\section{DEPOSITORY OF FIGURED SPECIMENS}

The specimens illustrated on Plates 1-7 are deposited in the Museum of Natural History, Basel, Switzerland, under the numbers C 34576 to C 34618 .

\section{SYSTEMATIC DESCRIPTIONS}

\section{Family CALCISPHAERULIDAE Bonet, 1956}

Genus PITHONELLA Lorenz, 1901

\section{Pithonella thayeri Bolli}

(Plate 1, Figures 1-7)

Pithonellia thayeri Bolli 1974, p. 853, pl. 1, fig. 9-12; pl. 8, fig. 9-12; pl. 9, fig. 1-12; pl. 21, fig. 3 .

Because of their large, irregularly shaped calcite crystallites which form the outer layer, the specimens compare well with those from the Indian Ocean DSDP Site 261 (Leg 27). The specimen on Plate 1, Figures 2 and 4, has a thin second inner layer which corresponds to the layer of small crystallites seen in a Site 261 specimen (Bolli, 1974, pl. 9, fig. 8). The Oxfordian-Tithonian occurrence of Pithonella thayeri at Site 261 is here extended to the upper Hauterivian on the basis of nannofossil evidence.

\section{Pithonella sp. cf. $P$. thayeri Bolli}

(Plate 1, Figures 8, 9)

Strongly corroded large crystallites form the test surface of this specimen which is here questionably placed in Pithonella thayeri.

\section{Pithonella gustafsoni Bolli}

(Plate 2, Figures 3-6)

Pithonella gustafsoni Bolli, 1974, p. 854, pl. 3, fig. 9-12; pl. 12, fig. $7-12$; pl. 13 , fig. $1-2$; pl. 22 , fig. 3 .

The surface features of the figured specimens compare well with the Aptian-Albian forms from the Indian Ocean Site 260 of Leg 27. The illustrated Hole 416A specimens are from Core 15 which on the basis of calcareous nannofossil data falls within the upper Hauterivian Lithraphidites bollii Zone.

\section{Pithonella sp. E.}

(Plate 1, Figures 10-12)

The surface of the figured specimens is formed by irregularly shaped and sized calcite crystallites giving the test surface a rugged appearance. Isolated forms with such a surface have not previously been described from SEM views. More specimens are needed and in particular cross-sections and inside views to describe the form accurately as a new species. Thus, it is here designated as Pithonella sp. E (for Pithonella sp. A-D see Bolli, 1974).

Pithonella sp. E differs from $P$. thayeri in its generally much smaller and irregularly sized crystallites that form the outer surface of the test wall.

The figured specimens are from Cores 15 and 28 of Hole 416A, which on the basis of calcareous nannofossil data are Lithraphidites bollii (upper Hauterivian) and Calcicalathina oblonga Zone (upper Valanginian), respectively.

\section{Pithonella sp. cf. P. sphaerica (Kaufmann)}

(Plate 2, Figures 1-2, 7-12; Plate 3, Figures 1-12)

Pithonella cf. sphaerica (Kaufmann), Bolli, 1978. p. 822, pl. 4, fig. 7-12; pl. 5, fig. 1-12; pl. 6, fig. 1-12.

The species figured here as Pithonella sp. cf. P. sphaerica show various degrees of $\mathrm{CaCO}_{3}$ dissolution. The best preserved specimen with an almost complete outler layer, although also somewhat affected by corrosion, is illustrated on Plate 2, Figures 1,2. Its surface is virtually identical with those specimens from the upper Albian of the Leg 40 Walvis Ridge Site 363 (Bolli, 1978, pl. 5, fig. 1, 2). Other figured specimens, in particular the smooth-surfaced specimen shown on Plate 3, Figures 7-12, have apparently lost the whole outer layer by dissolution. By contrast, the specimen on Plate 3, Figures 3, 4 has only a small portion of the outer lay still preserved. The outer surfaces of the specimens shown on Plate 2, Figures 7-12 are considerably corroded. On Plate 3, Figures 7-12, the outer layer is totally removed, and the smooth, shiny surface of the inner layer is apparently also the product of dissolution.

Because of the limited number of SEM-investigated specimens, one cannot be certain that all the specimens affected by different degrees of dissolution, included here in Pithonella sp. cf. P. sphaerica, belong to the same species. The interior space of virtually all specimens is filled with a dense calcite core. Of particular interest is the specimen on Plate 3, Figures 11, 12, which has an operculum in its forming stage with the cover still attached. A similar stage was previously seen in a specimen of Pithonella francadecimae (Bolli, 1974, pl. 15, fig. 5, 6).

Specimens recognized here as Pithonella sp. cf. $P$. sphaerica occur in all examined Hole 416A samples. They are by far the most common of the recognized taxa and in a few samples occur as floods in the 44/63-micron fraction (see Figure 2).

Pithonella sphaerica was originally described from a polished section of the Senonian part of the Seewerkalk of central Switzerland. Isolated Aptian-Albian specimens from the Leg 40 Walvis Ridge Site 363 were tentatively named $P$. sp. cf. $P$. sphaerica. The specimens recorded here as $P$. sp. cf. $P$. sphaerica occur in the Tithonian to Hauterivian. This indicates that the species has a long range from Upper Jurassic to Upper Cretaceous. It has to be kept in mind, however, that spherical specimens strongly affected by $\mathrm{CaCO}_{3}$ dissolution and identified as $P$. sp. cf. $P$. sphaerica could, in fact, belong to different spherical species whose outer portions have at least partially been dissolved. Further, it also still remains to be determined whether the 
Upper Jurassic and Lower Cretaceous forms recognized as $P$. sp. cf. $P$. sphaerica are directly comparable with the original species from the Senonian Seewerkalk.

\section{Genus PIRUMELLA Bolli, n. gen.}

Type species: Pirumella edithvincentae Bolli, n. gen., n. sp.

Description of genus: Test elongate, pear shaped, with one wide and one distinctly narrower and more slender end. In axial section, circular to ovate. One or more layers are formed by calcite crystallites. The number of layers forming the test wall and the size of individual crystallites forming them are regarded as species characters. No apertures have been observed in the examined specimens. It is assumed, however, that such apertures similar to those in other Calcisphaerulidae may form at a certain stage of the cyst. The interior of the test is hollow; it may be filled wholly or partially by a dense calcite core formed during diagenesis in the sediment.

$P$. sliteri and $P$. piriformis are included in the Genus Pirumella, in addition to the type species, $P$. edithvincentae.

\section{Pirumella edithvincentae Bolli, n. sp.}

(Plate 4, Figures 1-12)

Description of species: Test elongate, pear shaped and circular in axial section. One end broadly rounded, the opposite distinctly narrower, moderately rounded to pointed. Largest diameter of test is slightly above middle of longitudinal axis, towards the broad end. Test wall consists of two layers. Outer layer, about 6 microns thick, formed mainly by large calcite crystallites of up to 16 microns in diameter. Individual crystallites are of an irregular size and shape, giving the test a rugged appearance. Inner layer is approximately 2 microns thick and consists of angular rod-like and tabular, in some specimens more massive calcite crystallites. They are irregularly and loosely arranged with open interspaces and with their long axes perpendicular to the test surface. The inner space of the pear-shaped test, particularly in its wider end, is filled with a spherical core of dense calcite, apparently a secondary feature. No apertures were seen in the examined specimens.

Dimensions of holotype: Length 76 microns, greatest width: 58 microns.

Biostratigraphic occurrence: Lithraphidites bollii Zone, upper Hauterivian (on basis of calcareous nannofossils).

Lithology of type sample: Gray, calcareous silty clay.

Locality of holotype and figured paratypes: DSDP Leg 50, Sample 416A-8-6, 145-147 cm, Moroccan Basin, eastern Atlantic, $32^{\circ} 50.18^{\prime} \mathrm{N}$, $10^{\circ} 48.06^{\prime} \mathrm{W}$. Water depth 4191 meters, 1118.0 meters sub-bottom.

Diagnosis: Pirumella edithvincentae $\mathrm{n}$. $\mathrm{sp}$. differs from $P$. sliteri $\mathrm{n}$. sp. in its much coarser calcite crystals forming the outer layer and in the more pointed broad and narrow ends. $P$. edithvincentae differs from $P$. piriformis (Keupp) in its circular axial section of the test and in the much thinner inner layer. The crystallites forming the individual layers of $P$. piriformis and their arrangements cannot be seen in the cross-sections ilustrated by Keupp.

Name: The species is named for Edith Vincent, paleontologist, DSDP Leg 50, Scripps Institution of Oceanography, La Jolla, California.

Pirumella sliteri Bolli, n. sp.

(Plate 5, Figures 1-12; Plate 6, Figures 1-6)

Description of species: Test elongate, pear-shaped, circular in axial section. Greatest diameter of test slightly above middle of longitudinal axis, toward the broad end of the test. One end broadly rounded to almost plane, the opposite end distinctly more pointed but still rounded. Test wall consists of two layers, the outer layer is about 4 microns thick and formed by small, 1-2 micron, irregular calcite crystallites. The outer surface viewed under the light microscope has a smooth, shiny appearance, which is probably the result of partial $\mathrm{CaCO}_{3}$ dissolution. Inner surface of outer layer smooth, with small pore-like openings between radially arranged small, rod-like crystallites which here fill the spaces between the larger crystals forming the outer wall layer. Inner layer 1 to 2 microns thick, consisting of angular, thin, tabular calcite crystallites with no or only very narrow interspaces between them. Long axes of these crystallites are perpendicular to the test surface, often with no other preferred orientation, or several crystallites form groups with long axes that may be arranged parallel to the surface. No apertures were seen in the examined specimens. The inner spaces of the pear-shaped tests, particularly in their wider ends, is filled with a spherically shaped core of dense calcite, apparently a secondary feature.

Dimensions of holotype: Length: 70 microns, greatest width: 54 microns.

Biostratigraphic occurrence: Lithraphidites bollii Zone, upper Hauterivian (on basis of calcareous nannofossils).

Lithology of type sample: Gray, calcareous silty clay.

Locality of holotype and figured paratypes: DSDP Leg 50, Sample 416A-9-3, 98-100 cm, Moroccan Basin, eastern Atlantic, $32^{\circ} 50.18^{\prime} \mathrm{N}$, $10^{\circ} 48.06^{\prime} \mathrm{W}$. Water depth 4191 meters, 1122 meters sub-bottom.

Diagnosis: Pirumella sliteri $\mathrm{n}$. $\mathrm{sp}$. differs from $P$. edithvincentae $\mathrm{n}$. sp. in its smaller calcite crystallites forming the outer layer, providing a fairly smooth surface of the test. Both the broad and the narrow ends are less pointed. $P$. sliteri differs from $P$. piriformis (Keupp) in its circular axial section of the test and in the much thinner inner layer. Crystallites forming the individual layers of $P$. piriformis and thus their arrangement cannot be seen in the cross-sections illustrated by Keupp.

Name: The species is named for William V. Sliter, paleontologist, DSDP Leg 50, U.S. Geological Survey, Menlo Park, California.

\section{Family CALPIONELLIDAE Bonet, 1956}

The following Calpionellidae species were recovered as isolated specimens from the samples investigated for Calcisphaerulidae:

?Calpionellidae sp.

(Plate 6, Figures 7, 8)

Genus CALPIONELLA Lorenz, 1902

Calpionella alpina Lorenz

(Plate 6, Figures 9-12)

Genus TINTINNOPSELLA Colom, 1948

Tintinnopsella carpathica (Murgeanu and Filipescu) (Plate 7, Figures 1-2)

Genus CALPIONELLITES Colom, 1948

Calpionellites darderi (Colom)

(Plate 7, Figures 3-6)

Genus REMANIELLA Catalano, 1965

\section{?Remaniella murgeanui (Pop)}

(Plate 7, Figures 7-12)

A single ?Remaniella specimen in which well-preserved crystallites form the test surface differs from the other species figured. The small crystallites are typically aligned in rows, with larger crystallites occasionally interspersed. This closely matches the several calpionellid specimens figured by Aubry et al. $(1975$, pl. 1) from the marly Berriasian north of Djebel Oust, Tunisia.

\section{ACKNOWLEDGMENTS}

I am indebted to Edith Vincent, Scripps Institution of Oceanography, La Jolla, California, and W. V. Sliter, U. S. Geological Survey, Menlo Park, California, for kindly suggesting this study. I wish to thank J. Remane, University of Neuchatel, for discussing the Calpionellidae figured in this paper; to J. P. Beckmann and Katharina Perch-Nielsen, both Federal School of Technology, Zürich, for critically reading the manuscript and for discussing problems of the Lower Cretaceous nannofossil zone schemes. H. E. Franz, from the same institution, took the SEM micrographs, and U. Gerber carried out the photographic work for the plates. 


\section{REFERENCES}

Aubry, M. P., Bignot, B., Bismuth, H., and Remane, J., 1975. Premiers résultats de l'observation au M. E. B. de la lorica des calpionelles et de quelques microfossiles qui leur sont associés, Revue de Micropaléontologie, v, 18, p. 127-152.

Bolli, H. M., 1974. Jurassic and Cretaceous Calcisphaerulidae from DSDP Leg 27, Eastern Indian Ocean. In Veevers, J. R., Heirtzler, J. R., et al., Initial Reports of the Deep Sea Drilling Project, v. 27: Washington (U. S. Government Printing Office), p. 843-907.

1978a. Cretaceous and Paleogene Calcisphaerulidae from DSDP Leg 40, Southeastern Atlantic. In Bolli, H.
M., Ryan, W. B. F., et al., Initial Reports of the Deep Sea Drilling Project, v. 40: Washington (U. S. Government Printing Office), p. 819-838.

1978b. Upper Jurassic Calcisphaerulidae from DSDP Leg 44, Site 391C, Blake Bahama Basin, Western North Atlantic. In Benson, W. E. and Sheridan, R. E., et al., Initial Reports of the Deep Sea Drilling Project, v. 44: Washington (U. S. Government Printing Office), p. 911-920.

Keupp, H., 1977. Ultrafazies und Genese der Solnhofener Plattenkalke, Abh. Naturhist. Ges. Nuernberg e.V., v. 37, p. 1-128. 


\section{PLATE 1}

Figures 1-7 Pithonella thayeri Bolli.

1. Side-apertural view of a specimen with inner space filled with calcite, Sample 416A-9-3, $98-100 \mathrm{~cm}, \times 750$, C 34576 .

2. Oblique apertural view of another specimen, Sample 416A-8-6, 145-147 cm, $\times 750$, C 34577.

3. Detail of outer wall of specimen shown in Figure 2, $\times 3000$.

4. Detail of apertural area of specimen shown in Figure 2, showing the thick, coarse outer wall and the thinner inner layer composed of smaller crystallites. Crystallites on lower right are part of the calcite core filling the inner space of the spherical test, $\times 3000$.

5. Side view of a specimen with questionable apertural area at top, Sample 416A-9-3, 98$100 \mathrm{~cm}, \times 750, \mathrm{C} 34578$.

6. Detail of outer wall of specimen shown in Figure $5, \times 3000$.

7. Side view of specimen, apertural area at top, Sample 416A-9-3, 98-100 cm, ×750, C34579.

Figures 8, $9 \quad$ Pithonella sp. cf. P. thayeri Bolli.

8. Specimen with crystallites forming outer wall strongly corroded. Dense inner core visible at top where part of outer wall is removed, Sample 416A-9-3, 98-100 cm, $\times 750$, C 34580 .

9. Detail of top part of specimen shown in Figure $8, \times 3000$.

Figures 10-12 Pithonella sp. E.

10. Large spherical specimen with apertural area at top, Sample 416A-29-4, 12-13 cm, $\times 750$, C34581.

11. Smaller specimen, Sample 416A-15-5, 138-138 $\mathrm{cm}, \times 750, \mathrm{C} 34582$.

12. Detail of wall surface of specimen shown in Figure $11, \times 3000$. 
PLATE 1
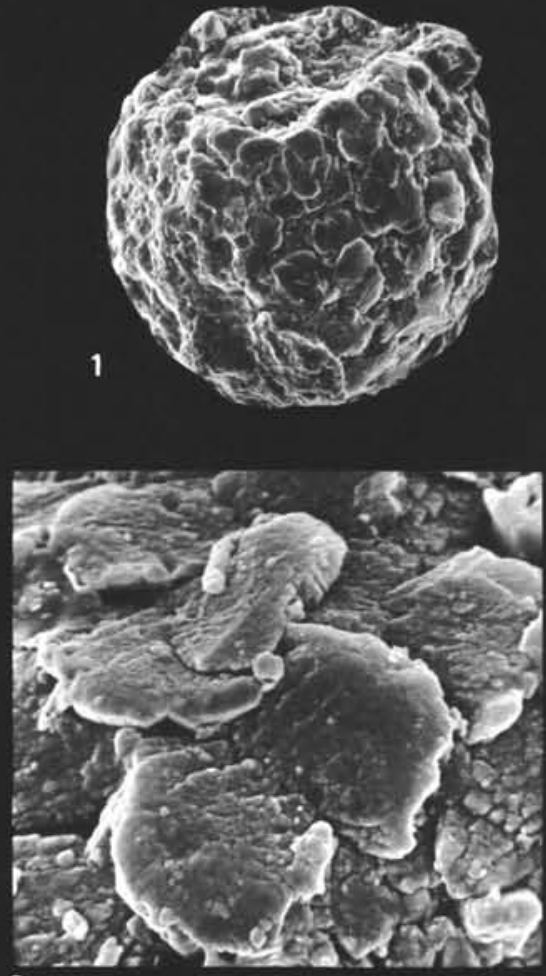

3
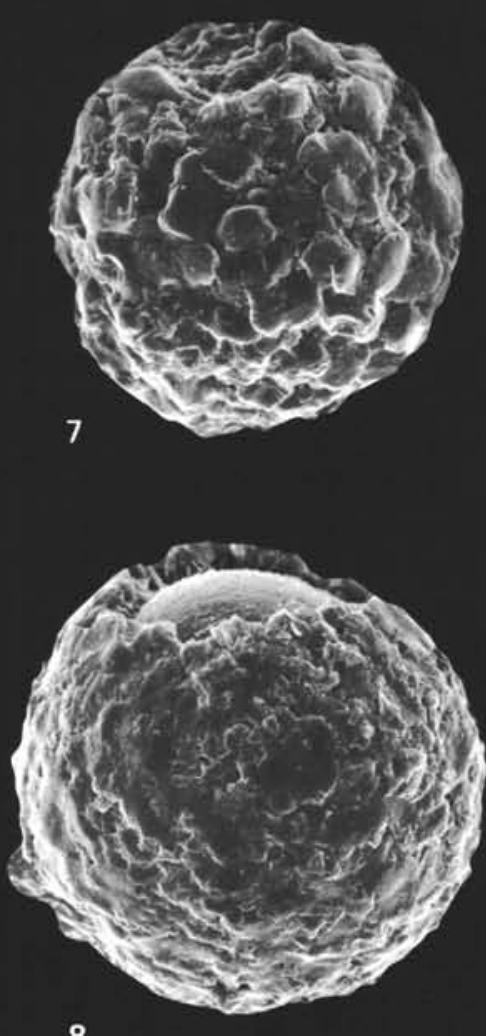
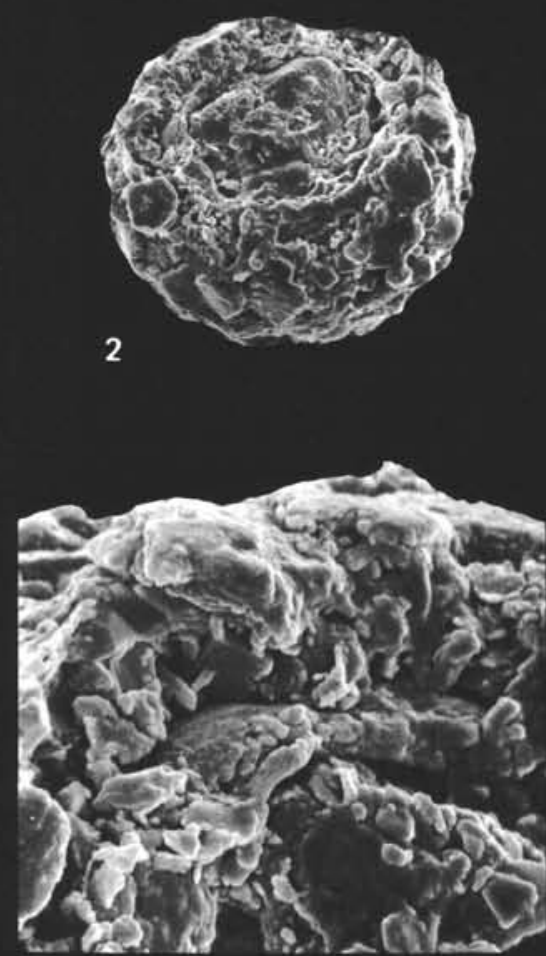

4
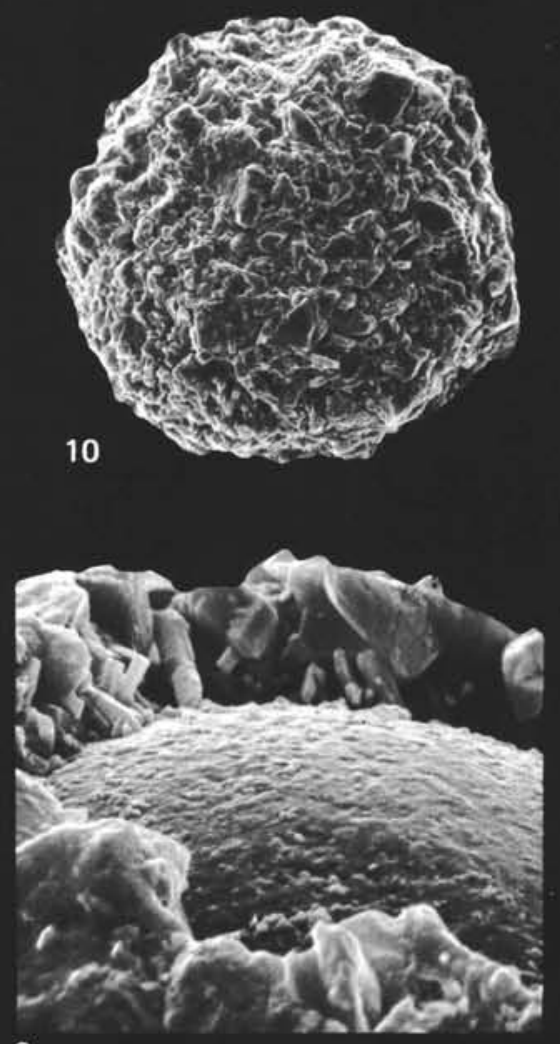

9
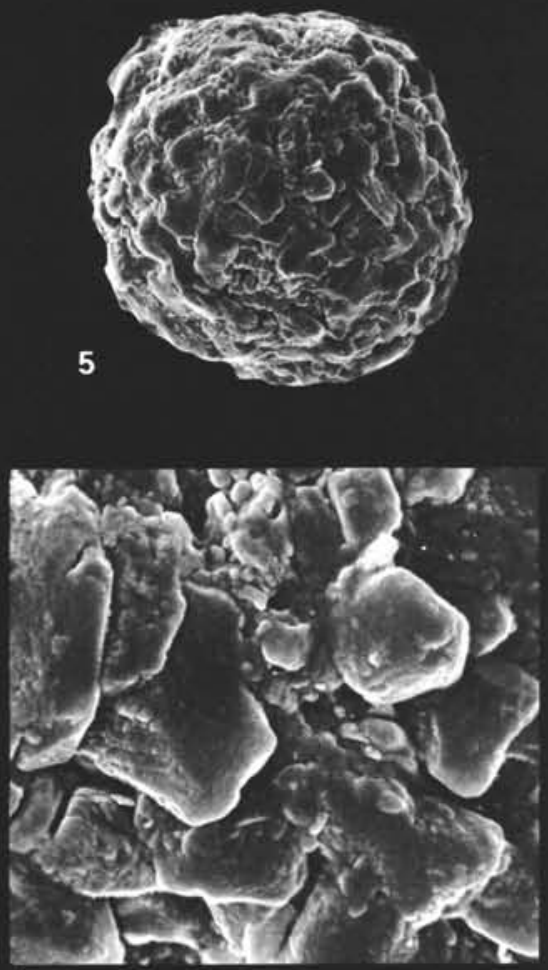

6
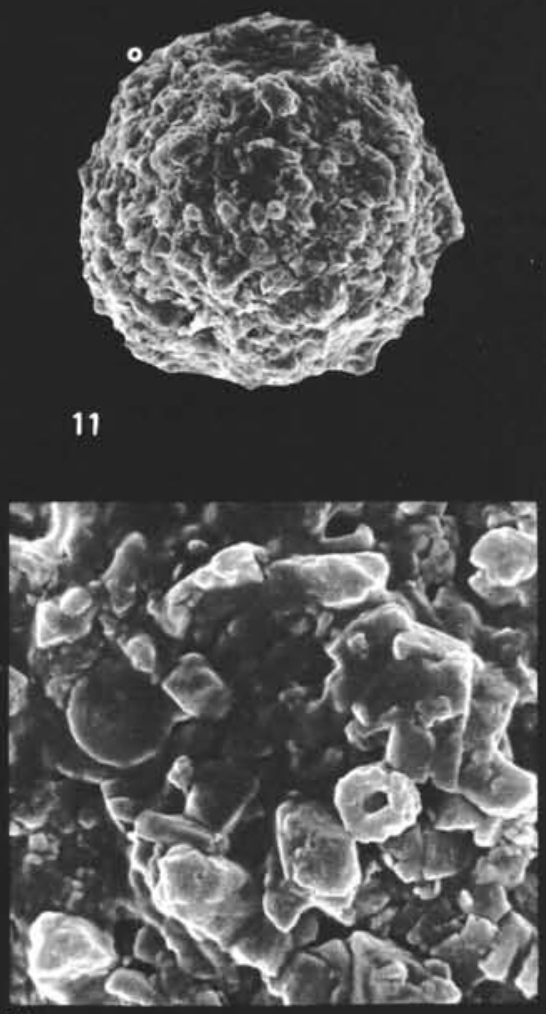

12 


\section{PLATE 2}

Figures 1, $2 \quad$ Pithonella sp. cf. P. sphaerica (Kaufmann).

1. Side view of specimen with apertural area at top, Sample 416A-8-6, 145-147 cm, $\times 750$, C 34583.

2. Detail of wall surface of specimen shown in Figure $1, \times 3000$.

Figures 3-6 Pithonella gustafsoni Bolli.

3. Oblique apertural view. Inner space of specimen filled with calcite, Sample 416A-15-5, $138-139 \mathrm{~cm}, \times 750$, C 34584 .

4. Detail of apertural area of specimen shown in Figure 3, with the single layer forming test wall, $\times 1800$.

5. Oblique apertural view of damaged specimen (lower right), Sample 416A-15-5, 138-139 cm, $\times 750$, C 34585 .

6. Detail of apertural area of specimen shown in Figure 5, $\times 1800$.

Figures 7-12 Pithonella sp. cf. P. sphaerica (Kaufmann).

7. Side view of slightly damaged specimen (left), Sample 416A-9-3, 98-100 cm, $\times 750$, C 34586 .

8. Detail of wall surface of specimen shown in Figure $7, \times 3000$.

9. Oblique apertural view of specimen, Sample 416A-9-3, 98-100 cm, $\times 750$, C 34587.

10. Oblique apertural view of specimen, inner space filled with calcite, Sample 416A-8-6, $145-147 \mathrm{~cm}, \times 750$, C 34588 .

11. Detail of part of apertural area of specimen shown in Figure 10. Calcite crystallites irregularly crosswise, $\times 3000$.

12. Detail of wall surface of specimen shown in Figure 10, oblique view, $\times 3000$. 


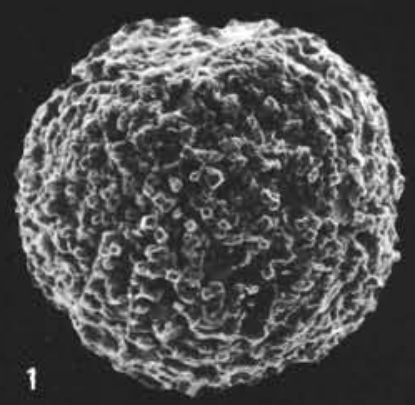

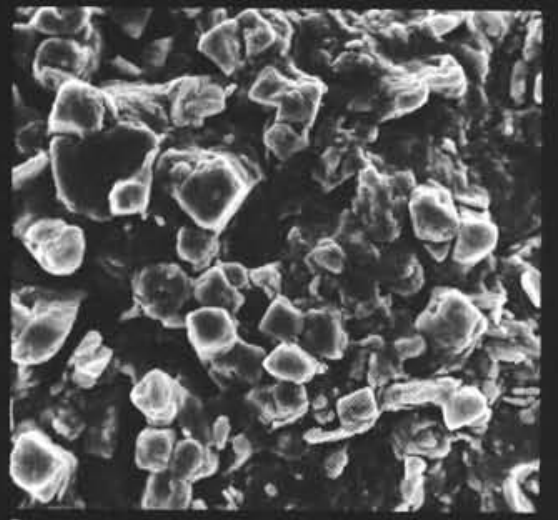

2

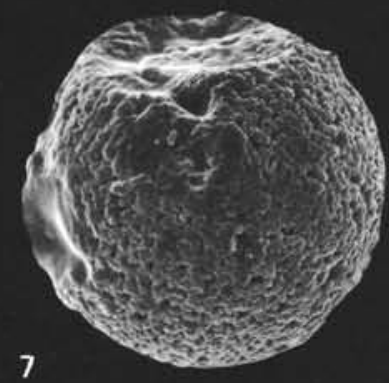

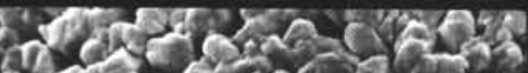
Q ECrower an mis

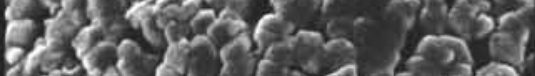

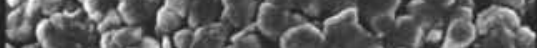

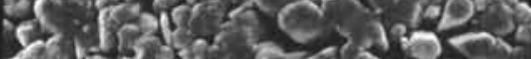
coves nuts

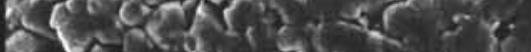

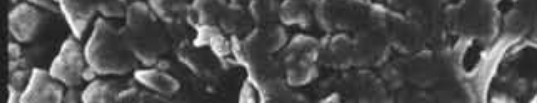

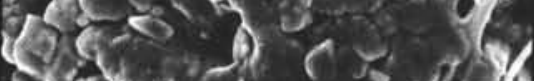

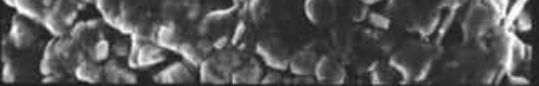

8
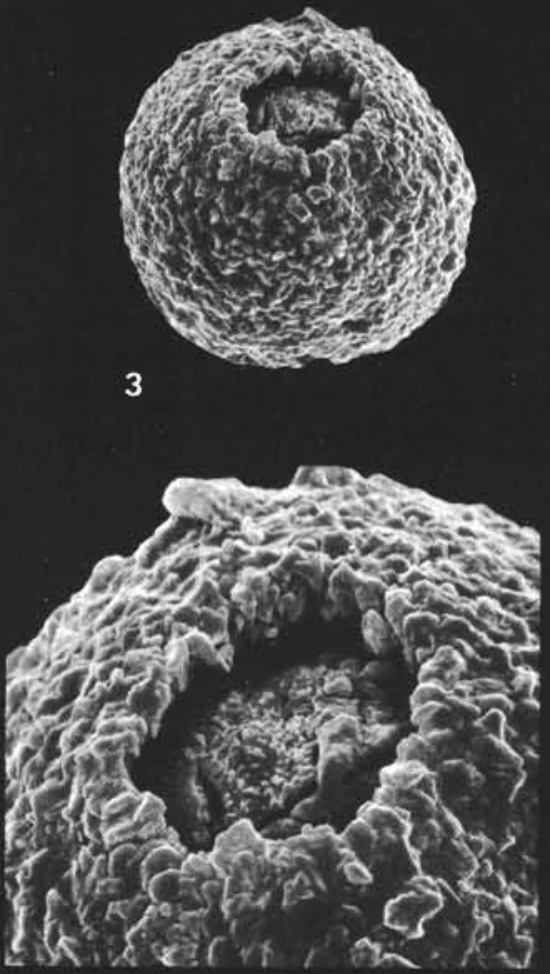
4
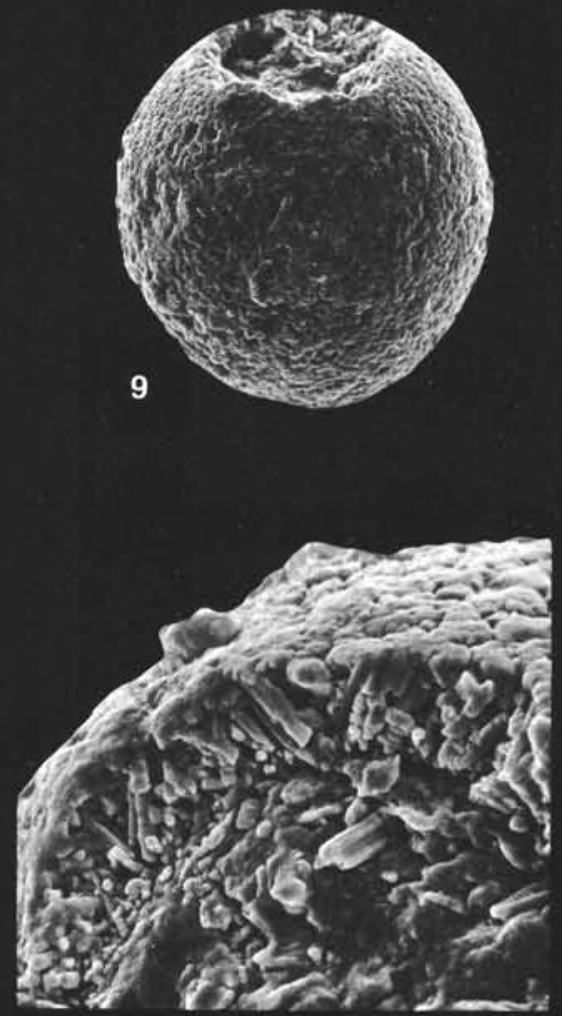

11
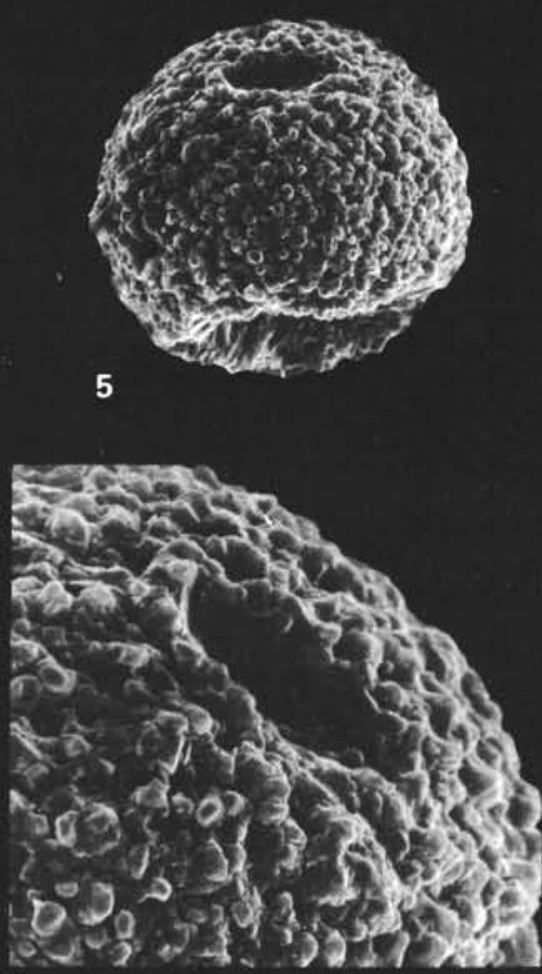

6
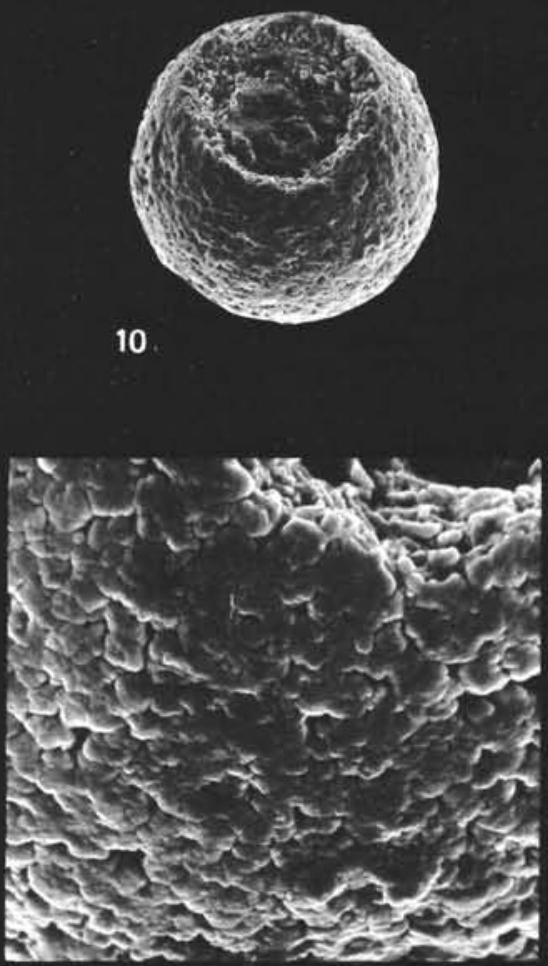

12 


\section{PLATE 3}

Figures 1-12 Pithonella sp. cf. P. sphaerica (Kaufmann).

1 . Specimen with outer wall layer strongly corroded, Sample 416A-9-3, 98-100 cm, $\times 750$, C 34589.

2. Detail of wall surface of specimen shown in Figure $1, \times 3000$.

3. Specimen where, except in top part of photo, the outer wall layer is removed, apparently as a result of calcium-carbonate solution, Sample 416A-9-3, 98-100 cm, $\times 750$, C 34590 .

4. Detail of specimen shown in Figure 3, showing portion of outer wall covering inner core, $\times 3000$.

5-12. Smooth-surfaced specimens where outer wall and possibly a second inner wall have been removed by calcium-carbonate dissolution.

5. Small specimen, Sample 416A-28-4, $12-13 \mathrm{~cm}$, $\times 750$, C 34591 .

6. Detail of wall surface of specimen shown in Figure 5, $\times 3750$.

7. Medium-sized specimen, Sample 416A$32-3,83-85 \mathrm{~cm}, \times 750, \mathrm{C} 34592$.

8. Detail of wall surface of specimen shown in Figure 7, $\times 6000$.

9. Large specimen showing corrosion of surface, Sample 416A-31-6, $98-100 \mathrm{~cm}, \times 750, \mathrm{C}$ 34593.

10. Detail of wall surface of specimen shown in Figure 9, $\times 3000$.

11. Specimen forming operculum with cover still attached. Part of surface of specimen strongly corroded and damaged (lower right). Sample 416A-31-6, 98-100 cm, $\times 750$, C 34594.

12. Detail of specimen shown in Figure 11, $\times 3000$. 

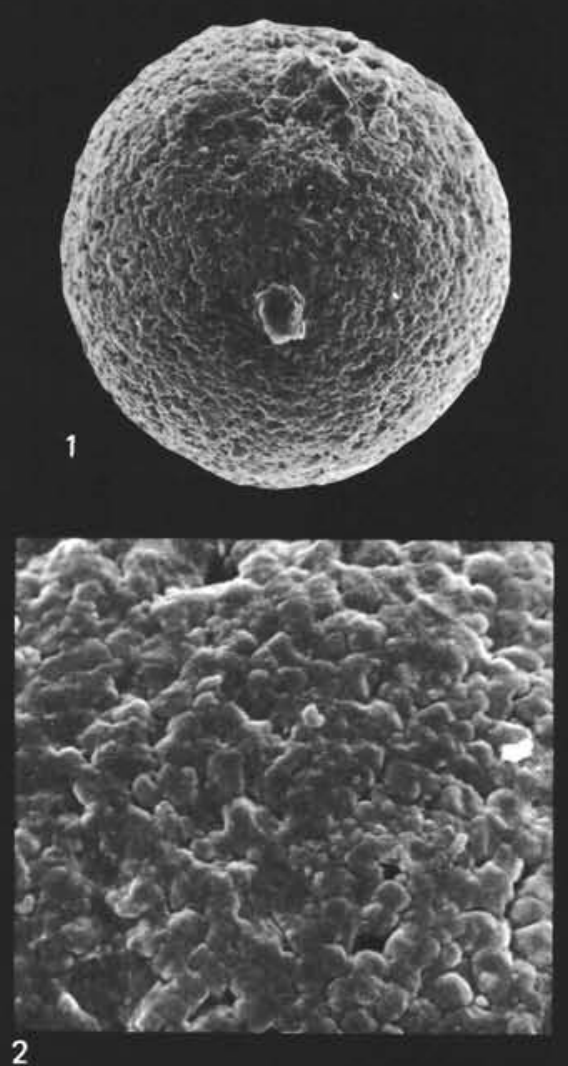

4
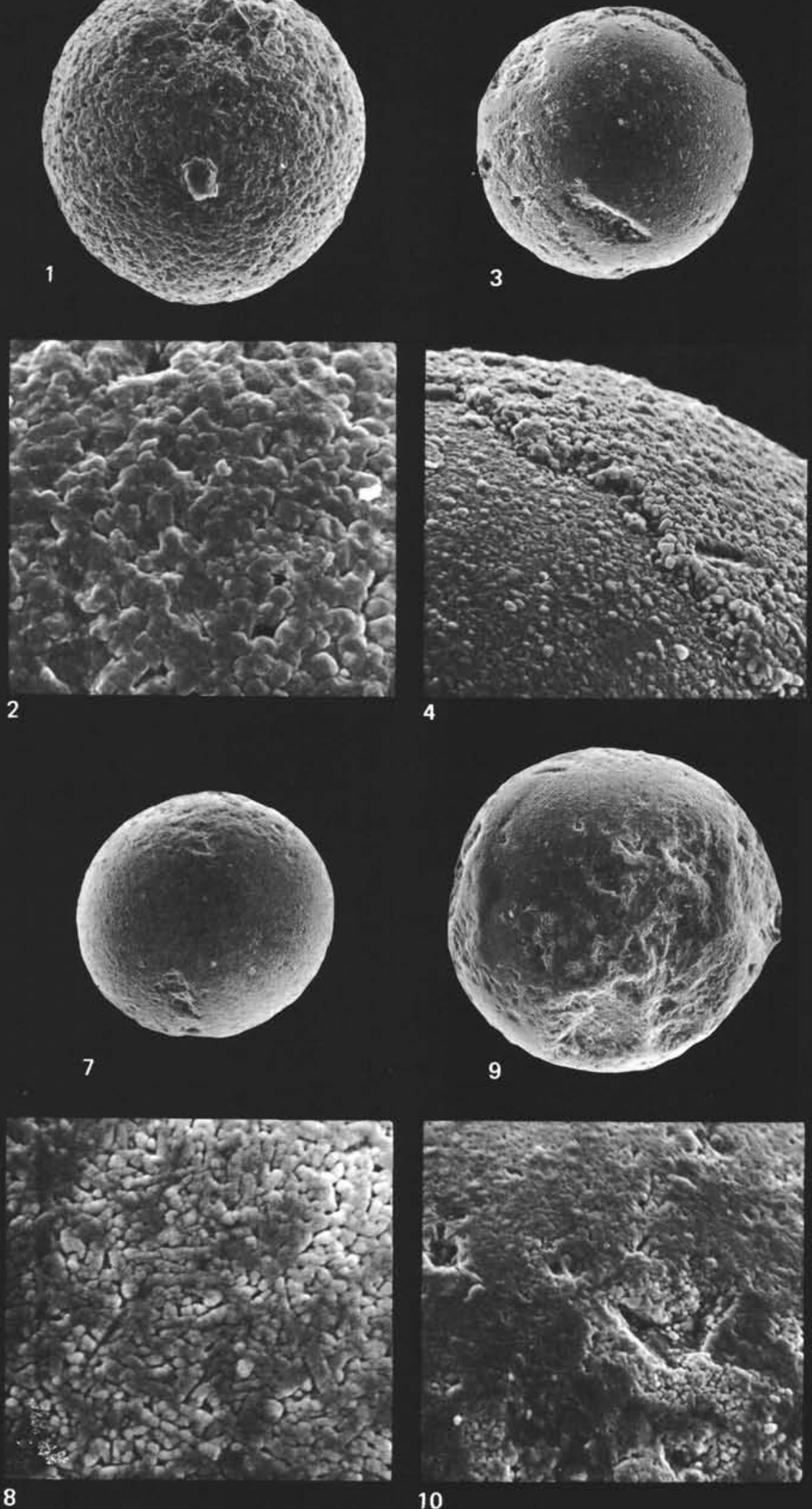

7

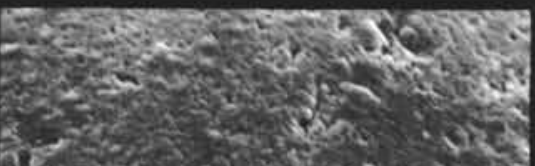

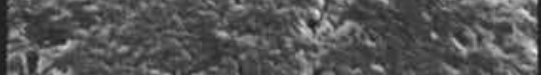

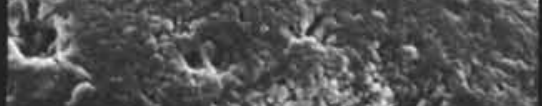

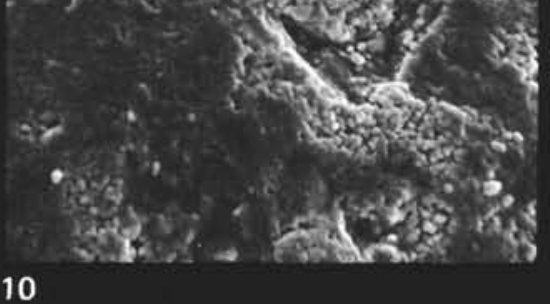

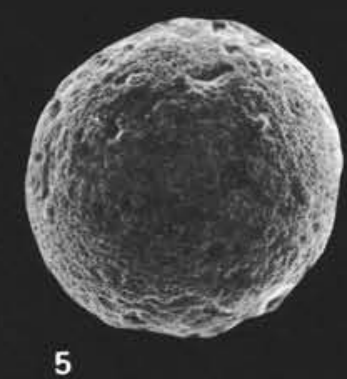

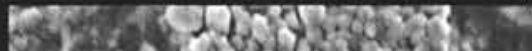

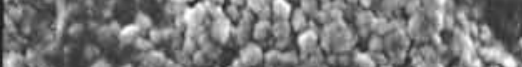

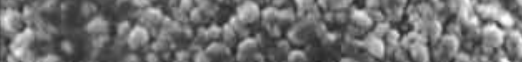

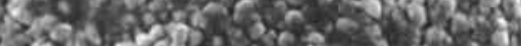
3300 aves.

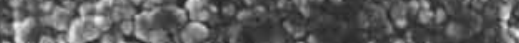

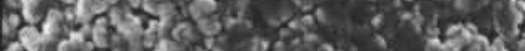

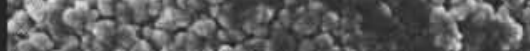

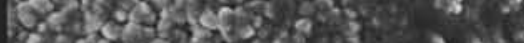
sescosering if.

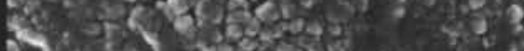

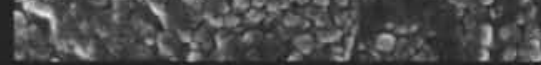
6
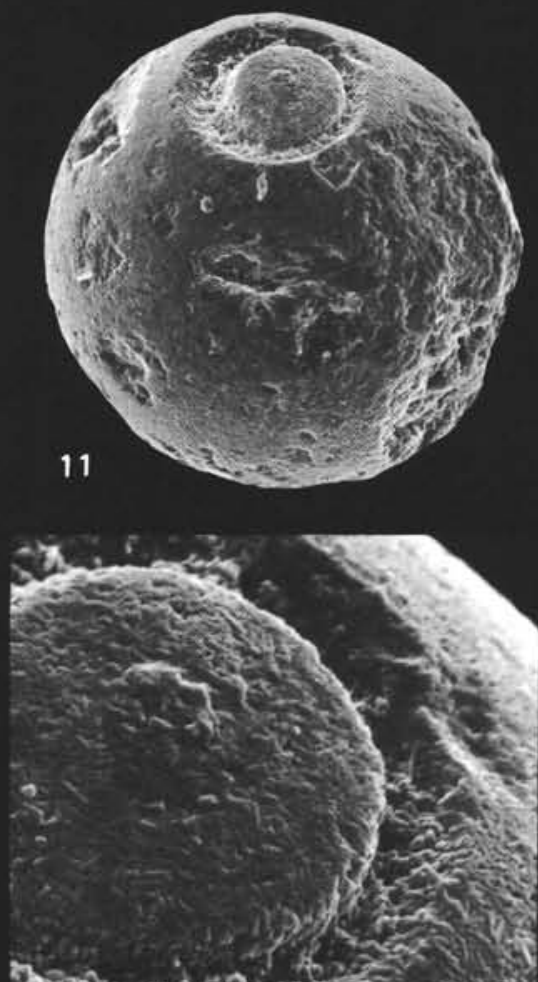

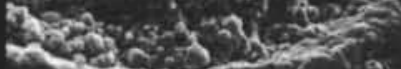

12 


\section{PLATE 4}

Figures 1-12 Pirumella edithvincentae Bolli, n. sp.

All specimens from Sample 416A-8-6, 145-147 cm.

1. Side view of holotype, $\times 750$, C 34595 .

2. Detail of wall surface of specimen shown in Figure $1, \times 3000$.

3 . Side view of paratype, $\times 750$, C 34596 .

4. Slightly oblique view of paratype, $\times 750, C$ 34597.

5. Paratype with partially removed wall showing cross-section of wall layers and inner hollow space, $\times 750$, C 34598 .

6. Detail of specimen shown in Figure 5, showing cross-section of the two layers forming the test wall, $\times 3000$.

7. Side view of paratype with parts of outer and inner layer removed. Portion of inner layer visible in center of photograph. Dense core with smooth surface, filling the inner space of the specimen, appears to the right and below the exposed portion of the inner layer. $\times 750$, C 34599.

8. Dense, spherical core filling inner space, removed from specimen. Attached to the left side of the core is the thin inner layer of the wall. $\times 1200$, C 34600 .

9. Detail of specimen shown in Figure 8. Loosely arranged, angular calcite crystallites forming the inner layer of the wall, $\times 6000$.

10. Paratype with outer and inner layer partially removed. Part of dense, spherical core filling inner space of specimen is clearly visible where both outer and inner wall layer have been removed, $\times 750$, C 34601 .

11. Detail of specimen shown in Figure 10. From top left to bottom right: Cross-section of outer layer, thin inner layer, surface of dense core, $\times 3000$.

12. Detail of specimen shown in Figure 10. Loosely arranged angular crystallites of inner layer on dense, smooth surface of spherical inner core, $\times 3000$. 
PLATE 4

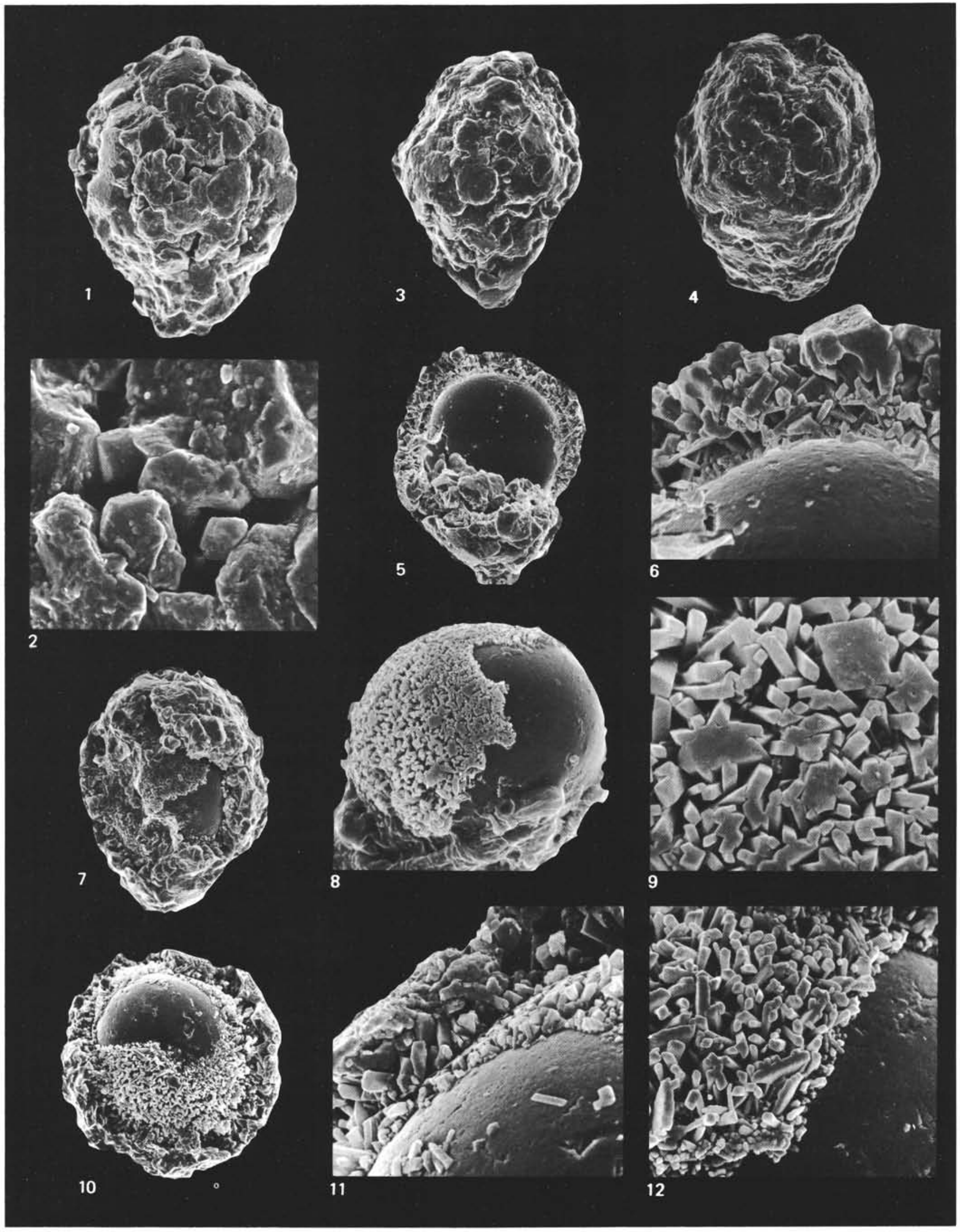




\section{PLATE 5}

Figures 1-12 Pirumella sliteri Bolli, n. sp.

All specimens from Sample 416A-9-3, 98-100 cm.

1 . Side view of holotype, $\times 750$, C 34602 .

2. Detail of wall surface of specimen shown in Figure $1, \times 3000$.

3. Side view of paratype, $\times 750$, C 34603 .

4. Detail of wall surface of specimen shown in Figure 3, $\times 3000$.

5. Side view of paratype, $\times 750$, C 34604 .

6 . Side view of paratype, $\times 750, C 34605$.

7. Cross-section of outer and inner layer and inside view of a broken specimen, $\times 1050$, C 34606.

8. Detail of specimen shown in Figure 7, showing cross-section of thin inner and more massive outer wall layer, $\times 3000$.

9. Cross-section of outer wall layer (part of a broken specimen), $\times 3000$, C 34607 .

10. Inside view of outer wall layer of specimen shown in Figure 9, $\times 6000$.

11. Paratype with outer and inner wall layer partly removed. Surface of inner layer, covering exposed dense, spherical inner core, visible on left, $\times 750$, C 34608 .

12. Detail of specimen shown in Figure 11. From left to right: outer layer, inner layer, core, $\times 3000$. 


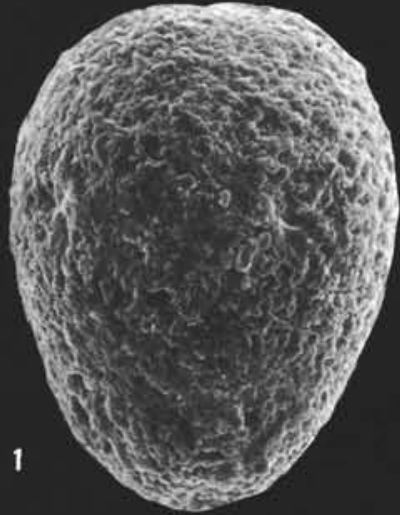

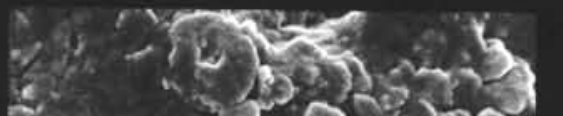
र०. 2 . a-ing

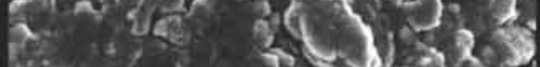

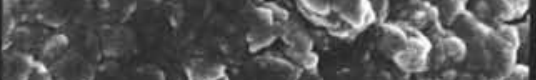

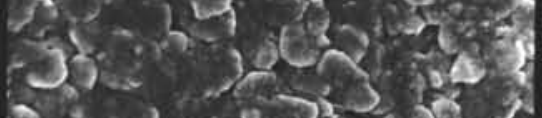

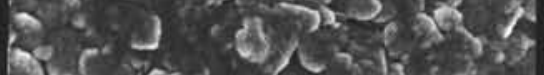
2
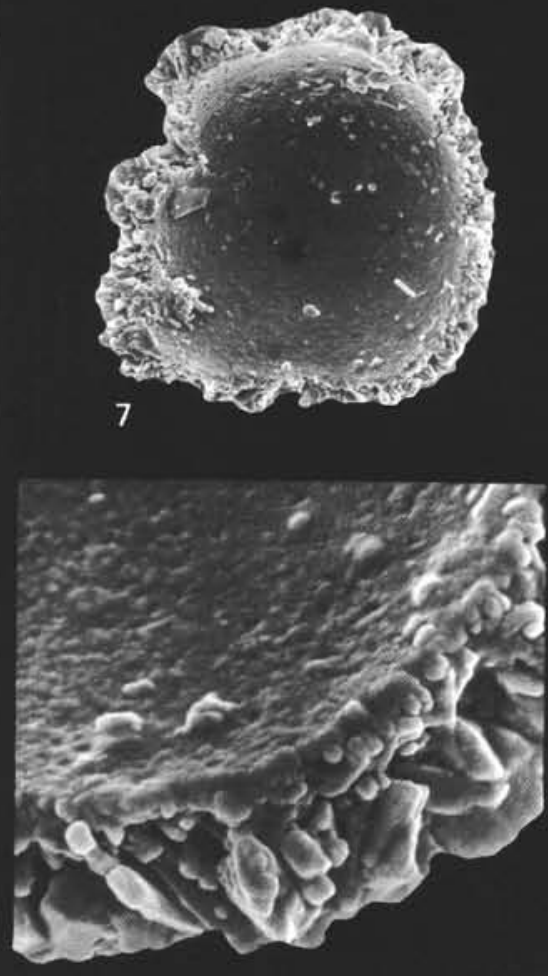

8

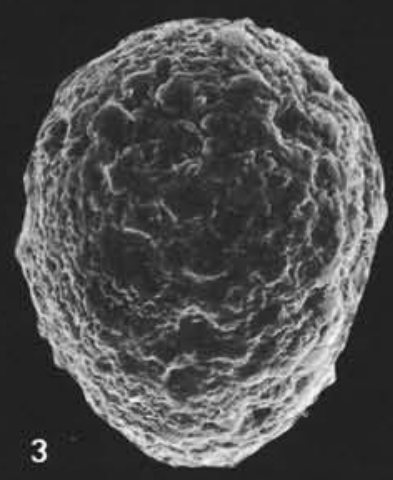

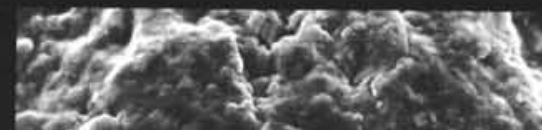

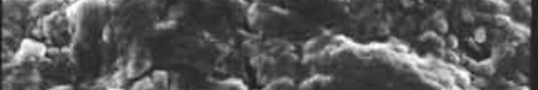

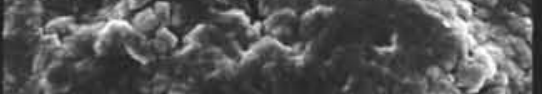

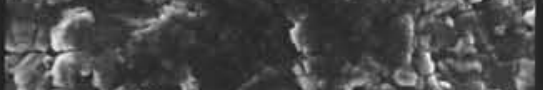

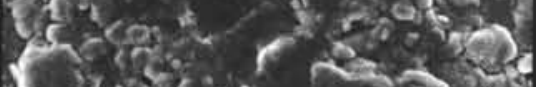

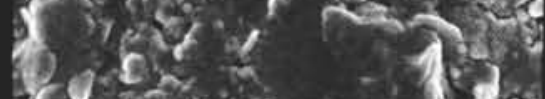
4

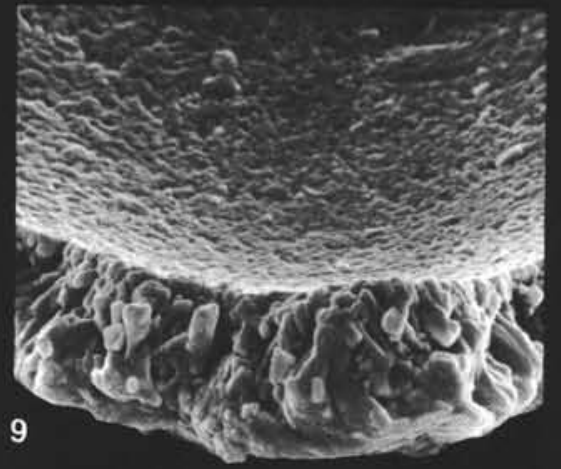

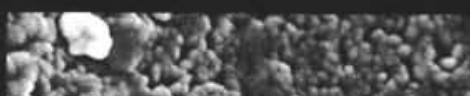

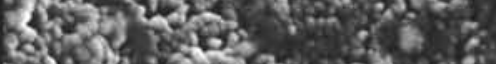

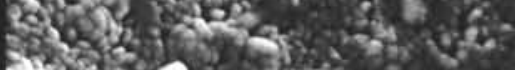
E)

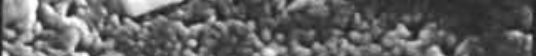

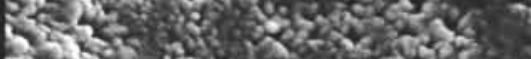

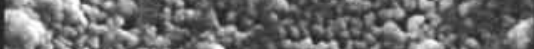

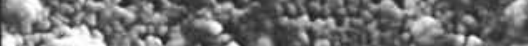

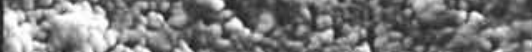

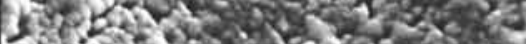

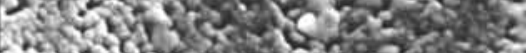

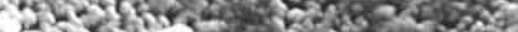
Tisur. 10
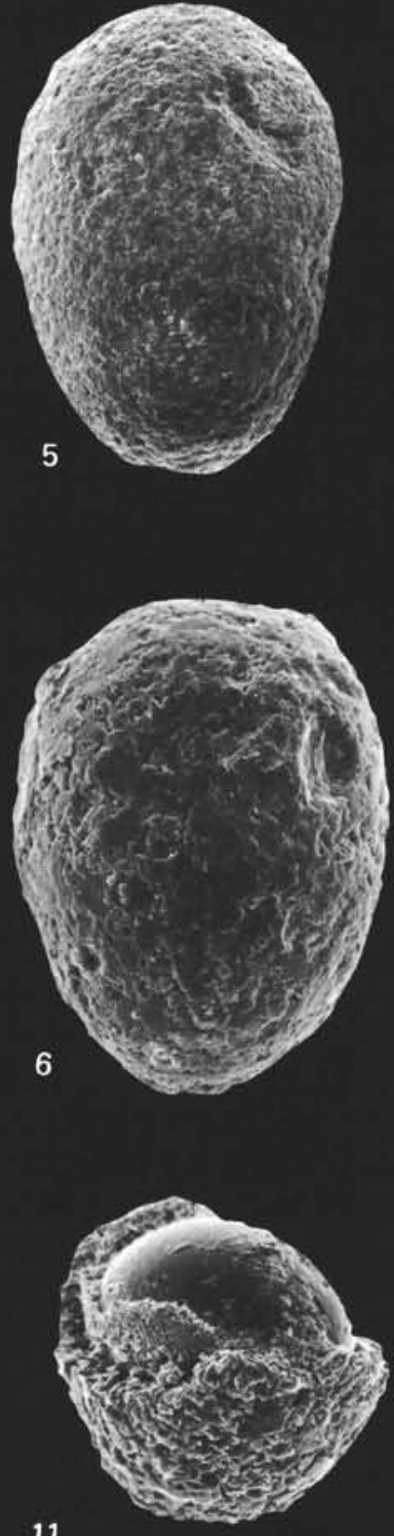

11

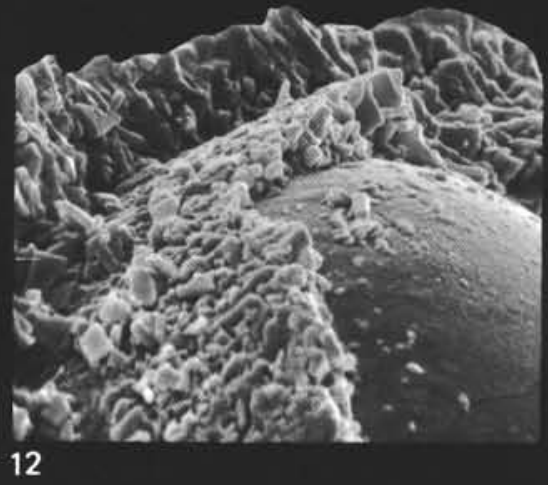




\section{PLATE 6}

Figures 1-7 Pirumella sliteri Bolli, n. sp.

All from Sample 416A-9-3, 98-100 cm.

1. Broken paratype showing outer and thinner inner wall layers. Interior of specimen partly filled with calcite or broken fragments of test, $\times 750$, C 34609 .

2. Detail of specimen shown in Figure 1. Crosssection, from top to bottom: outer layer, inner layer and inner space of specimen, partly filled, $\times 3000$.

3. Detail of lower central part of specimen shown in Figure 1. Outer layer on right side, surface of inner layer to the middle, $\times 3000$.

4. Detail of specimen shown in Figure 1. Outer surface of inner layer, $\times 6000$.

5. Paratype with thick outer and thinner inner wall layers partly removed. Portion of dense core, filling inner space exposed at top center, $\times 750$, C 34610 .

6. Detail of central part of Figure 5. Surface of inner layer shows arrangement of thin tabular crystallites oriented perpendicular to the test surface. Upper right of photograph shows broken portion of inner layer, $\times 3000$.

Figures 7, 8 ?Calpionellidae sp.

7. Oblique side and apertural view of lorica, Sample 416A-8-6, $145-147 \mathrm{~cm}, \times 750, \mathrm{C}$ 34611.

8. Detail of part of apertural area of specimen shown in Figure 8, showing a more massive outer wall consisting of larger crystallites, and a thin smoother second layer below, $\times 3000$.

Figures 9-12 Calpionella alpina Lorenz.

9. Side view of lorica, Sample 416A-45-3, 71-73 $\mathrm{cm}, \times 750$, C 34612 .

10. Side view of lorica of another specimen. Sample 416A-40, CC, $\times 750$, C 34613.

11. Detail of lorica surface of specimen shown in Figure $10, \times 3000$.

12. Oral view of another specimen with collar partly broken off, Sample 416A-45-3, 71-73 $\mathrm{cm}, \times 1200, \mathrm{C} 34614$. 

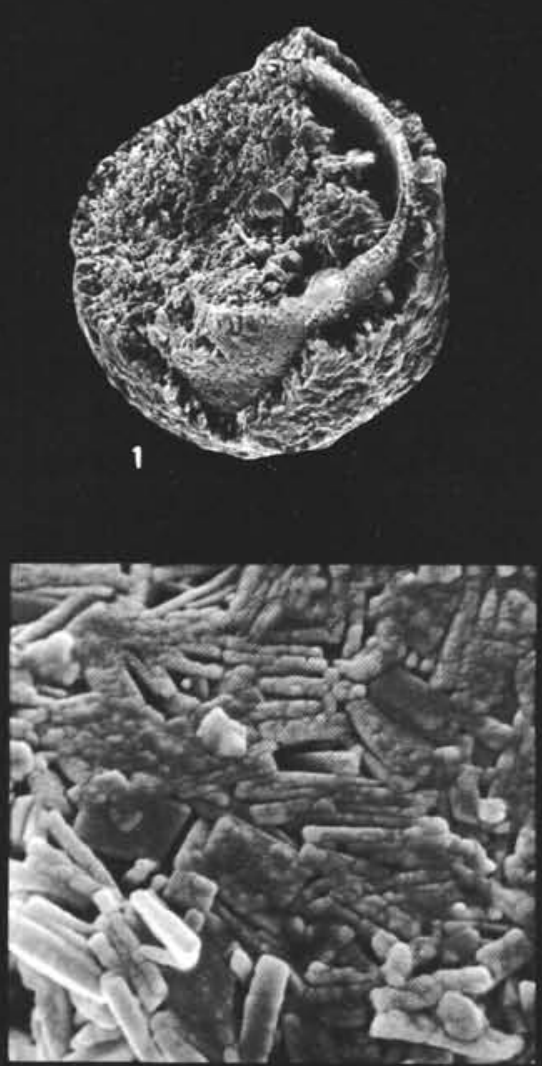

4
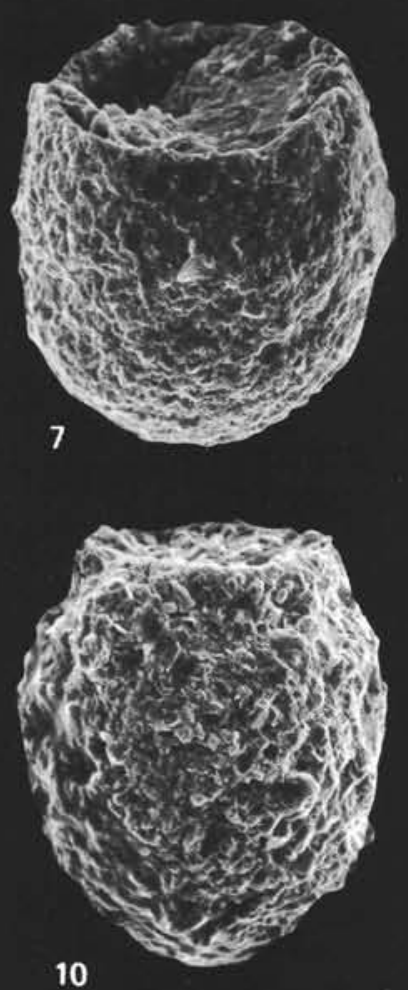
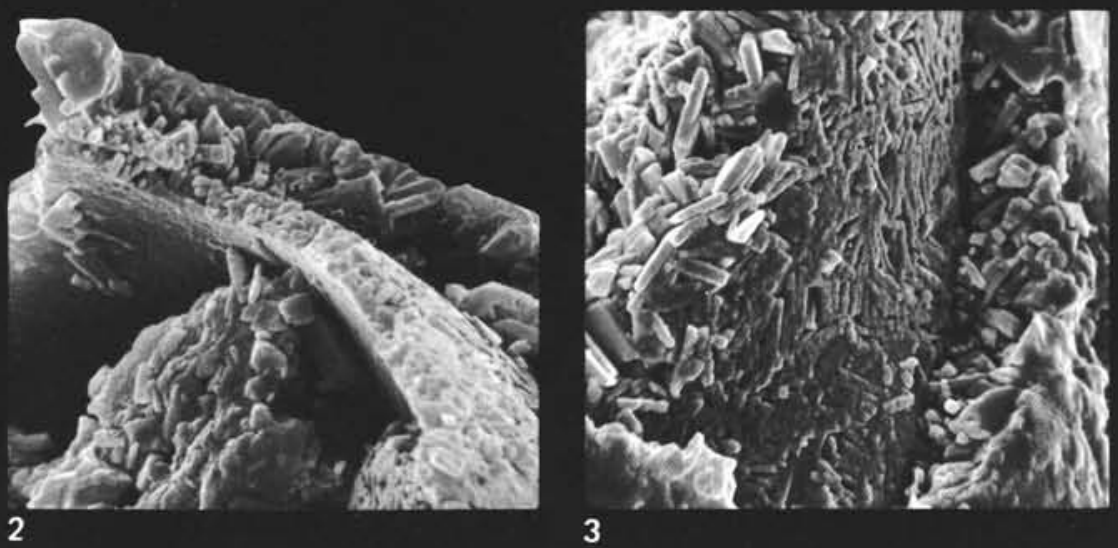

3

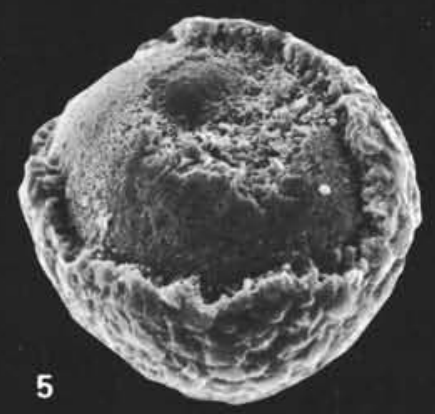

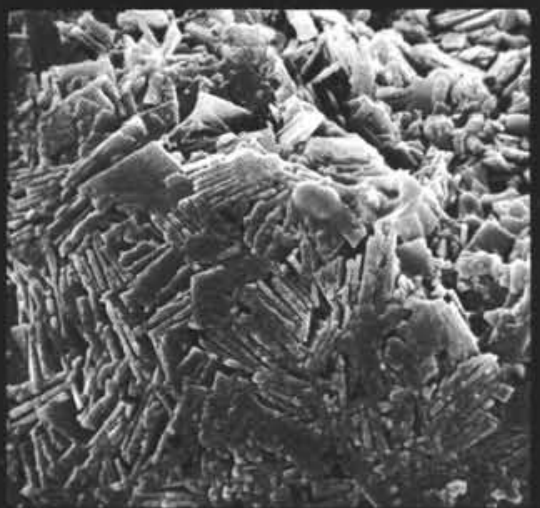

6
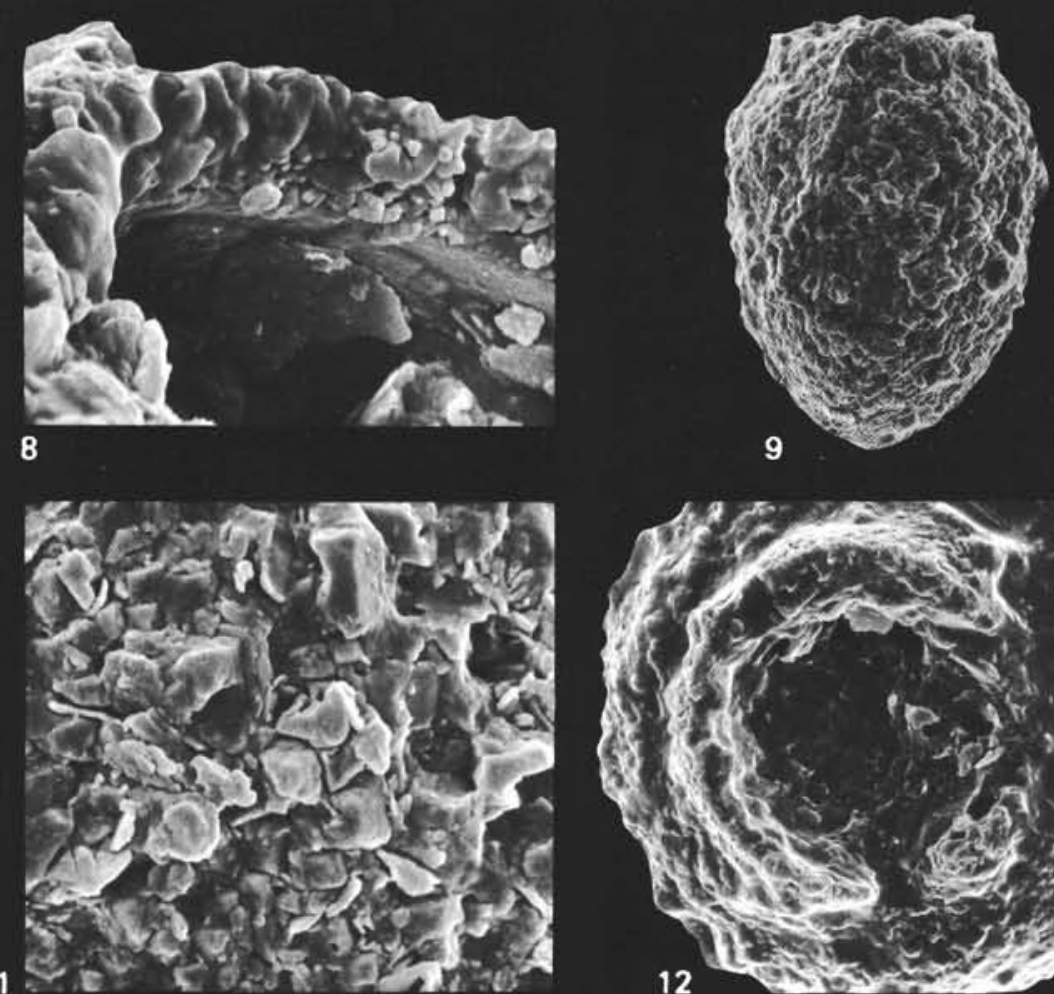


\section{PLATE 7}

Figures 1, 2 Tintinnopsella carpathica (Murgeanu and Filipescu).

1. Side view of lorica, Sample 416A-31-6, 98-100 $\mathrm{cm}, \times 750$, C 34615 .

2. Detail of lorica surface of specimen shown in Figure 1, Watznauaria barnese appears at upper left, $\times 3000$.

Figures 3-6 Calpionellites darderi (Colom).

3. Side view of lorica, Sample 416A-40 CC, $\times 750$, C 34616 .

4. Slightly oblique side view of lorica of another specimen, Sample 416A-45-3, 71-73 cm, $\times 750$, C 34617.

5. Detail of lorica surface of specimen shown in Figure $4, \times 3000$.

6. Same specimen as in Figure 4, oblique sideapertural view showing a lateral compression of lorica, $\times 750$.

Figures 7-12 ?Remaniella murgeanu (Pop).

7. Side view of lorica, upper part with collar apparently broken off, Sample 416A-9-3, 98-100 $\mathrm{cm}, \times 750, \mathrm{C} 34618$.

8. Detail of lorica rim of specimen shown in Figure 7 , oblique view, $\times 3000$.

9. Detail of lorica rim of specimen shown in Figure 7. Cross-section of wall. Arrangement of small individual crystallites in several overlying rows indicates that lorica wall consists of several layers, $\times 3000$.

10. Detail of lorica surface of specimen shown in Figure 7. Rows formed by small nodular crystallites are occasionally interspaced by distinctly larger ones, $\times 3000$.

11. Detail of specimen shown in Figure 7. Lower part of lorica with caudal appendage, $\times 1200$.

12. Caudal appendage of specimen shown in Figure 7 in axial view, showing arrangement of small knob-like crystallites, occasionally interspersed with distinctly larger ones, $\times 3000$. 

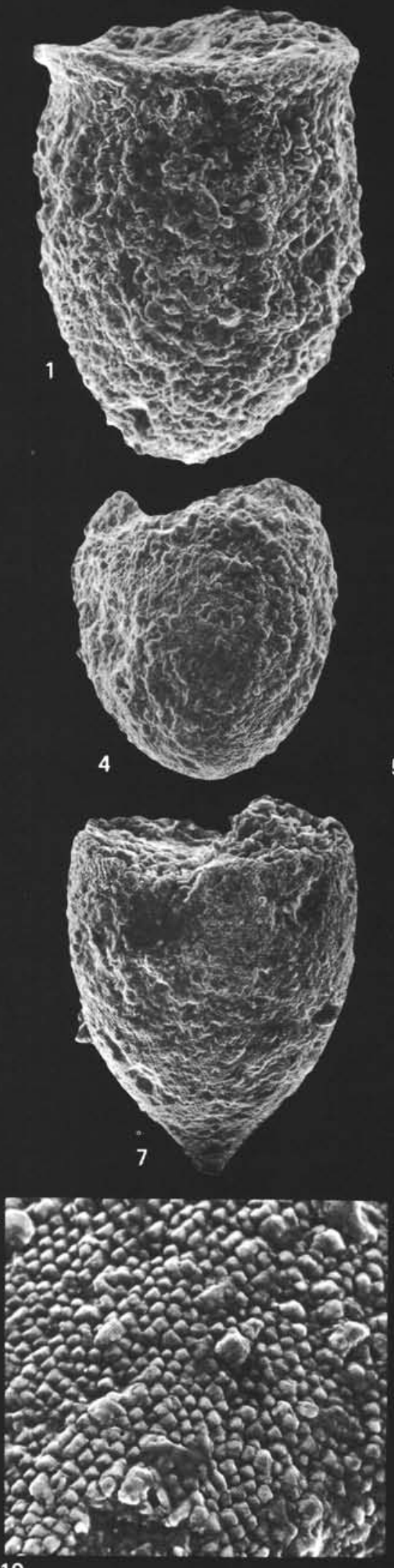

10
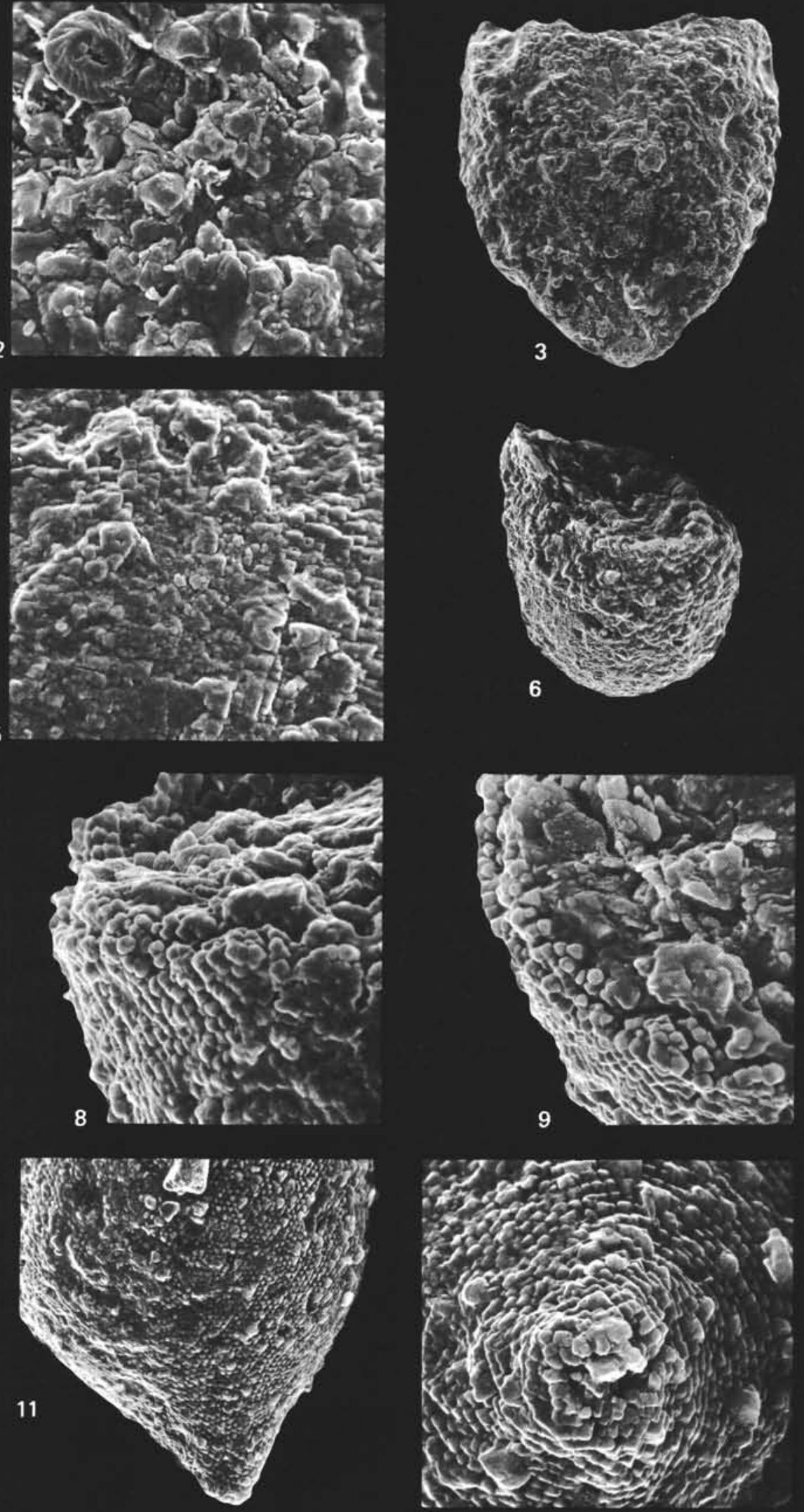